\title{
DOCUMENTATION ON TRADITIONAL COSTUME OF KHAMBA TRIBE OF TIBET IN EXILE- DHARAMSHALA, HIMACHAL PRADESH
}

\author{
CHAVI GOYAL \& PROF. SUMAN PANT
}

Ph. D Scholar, Banasthali University \& Dean, Department of Clothing and Textiles, Faculty of Home Science,

Banasthali University, Rajasthan

\begin{abstract}
India is known for its rich, colourful and varied heritage of clothing each representing a cultural tradition of its own. Reflecting true colourfulness and grace, Indian costumes offer the world the amazing styles resulting out of intermingling of cultures. An ethnographic research was conducted to study the tribal costume of the Tibetans residing in Exile: Dharamshala, Himachal Pradesh region of India. The article outlines the connotation of the Tibetans culture, elaborates the aesthetic characteristics, pattern, colour and compositional characteristics of their costumes of three tribes- Amdo, Khampa and Utsang in the Exile region. This article focuses on the Khampa costumes in the Exile region area as an example, through analysing the materials of these tribal costumes in the Dharamshala, the paper deeply analyzes the differences in cultural customs and dressing habits. A study reveals that the Tibetan region was colder than India leads to change in weather and climatic condition which accounted for a lesser number of clothes.

Due to its geographical location, this tribe's women wore lighter garments comprising of blouse and Chhupa as an overgarment. If women are married, the Pangdhen (Apron) was tied on the waist as a symbol of marriage. There was no significant change due to geographical location in the traditional costume which was worn persistently during ceremonial occasions and marriages by both men and women. The traditional costume has also undergone changes in terms of textiles, colour, and motifs as well as in draping style.

With modernisation and socio-economic development, the preferences of the modern tribal women have changed from the traditional way of dressing and adorning. And present generation was following western garments in daily wear or casual wear.

The study ideates that there are multicultural factors influencing different cultural identities, which can also be witnessed through the textiles and costumes of the tribes.

KEYWORDS: Costume, Khamba Tribe, Tibet In Exile- Dharamshala, Himachal Pradesh
\end{abstract}

Received: Jul 16, 2021; Accepted: Aug 06, 2021; Published: Sep 01, 2021; Paper Id.: IJHRDEC20214

\section{INTRODUCTION}

Tibet is a vast country on the roof of the world with the great Himalayan mountain ranges in the South, the Karakorum ranges in the West and the Kunbun ranges in the north. It has a century-old tradition of weaving woollen fabrics and of making many colourful costumes, which varied from region to region across the vast county.

The rich and varied costumes of the land of snows are little known to the outside world. They have been never 
studied and are now in real danger of disappearing forever. Before the Chinese invasion in 1951, Tibet has a very unique style of costumes. From nomads to the highest government official used to wear their traditional costume. The land was sparsely populated and regional styles of costumes were reflected in three main provinces of Amdo, Khamba, U-Tsang tribes. However, within each territory, numerous local styles were seen which was influenced by different climate and livelihoods of the people who live in isolation and microclimates. Distinct local styles of clothing were developed giving an instantly recognizable identity to the wearer. During the time period 1966-1978, the cultural revolution took place in Tibet where the Chinese communist regime tried to destroy the traditional costume by giving punishments to the person who were found in such dresses. This was the major threat to the culture and Costume of the region.

At a time when Tibetan civilization is threatened by sweeping modernization and by new aggressive $21^{\text {st }}$ Century style Colonization, people are losing familiarity with their own rich and ancient modes of dress and it is rare to see anyone wearing full traditional Costume, except on festival days or for tourist shows.

This study is an attempt to understand the clothing pattern of Tibetan Khamba tribe in exile. Recording of traditional Tibetan costumes and jewellery was done vis-a-vis with the present clothing patterns. This will also help to understand the social acceptability of the Tibetan culture in exile.

\section{METHODOLOGY}

An Ethnographic research was conducted to study the costumes of men and women of the Khamba tribe of Tibet in Exile. The selection of the locale for the study was Dharamshala, McLeod Gunj parts of Northern India as per accessibility \& mobility of the researcher and concentration of Tribe in this particular region. The Sampling technique used was purposive sampling technique. The sample chosen was Mr. Samten, Costume Director, Tibetan Institute of Performing arts, Mcleod Gunj, Dharamshala. The data was collected using methods including participant observation, face-to-face interviews, focus group discussion, photography and visual ethnography. Numerous field visits were carried out to document the details of traditional costumes of the Khamba tribe and to delineate the costumes and ornaments worn by the Men and women Khamba tribe by Richer class and Poorer class of the tribe.

Both the primary and secondary data collection with photographic documentation facilitated documentation of the study. The data was systematically analyzed to get detailed information regarding traditional costumes worn for different occasions supported by photographic evidence.

\section{FINDINGS \& DISCUSSIONS}

\section{Traditional Costume of Khampa Men and Women}

The tribe of Khamba is situated in rugged terrain, they are of robust physique, bold and daring extroverted temperaments. Thus their ornaments were exaggerated to show the strength of the men and the beauty of their women. The costumes of Khambas was flamboyant in the use of their exquisite, brocade and fur-trimmed robes. 


\section{Men Costume of Khamba Tribe (Figure.1)}

\section{A) Chhupa}

The robes were named as "Chuchen" with extra long and wide sleeves which touched the ground. The middle class prefer cotton or wool fabrics of brown, white and black colour. The rich Khamba tribe prefer brocade and silk fabric of red and yellow colour. Traditionally they wore robes made of pure wool in winters and occasionally with silk material. Their bulky robes were pulled up to the knees by long, wide, tasselled silk or cotton sash.

\section{B) Shirt}

Inside the robe, they wore loose cotton or silk Shirts of white colour called as Wo-Jueg embroidered edges on sleeves and collars. The asymmetrical loose shirts called "Wo-Jueg" which are till waist in length, Chinese collar and short sleeves for middle class and loose long sleeves till feet for richer Khamba men. The fabrics used were cotton or Silk by both categories of men.

\section{C) Trouser}

The loose pants worn by Khamba men were baggy woollen trousers tucked in their boots which gives ballooned effect from the top. The colour that they prefer was majorly white followed by black, burgundy and maroon colours. The fabrics used were silk and woollen but shifted to cotton as per climatic conditions of the region.

\section{D) Sash}

The chuchen is tied at the waist with a sash made of cotton or silk fabric of red colour with silk fringes. Tassels were used as an adornment for the robe.

\section{E) Hair Styling}

The hairs were braided into a long tail which is attached with red colour silk yarns of 2-3 meters and then wrapped twice on the head. As they belonged to the warrior community, they need to save them from the sword injury. The swords when hit on the head by other parties, the warrior is saved while fighting as silk yarn which has peculiar characteristics gummed yarn doesn't allow to hurt the head thus saving the life of the warrior.

\section{F) Footwear}

They wear black velvet shoes named as "Tey Lham" and "Ko Lham". The footwear preferred were Lham made of cotton, velvet, leather. The soles were made of pure leather. Most boots have leggings which were tied below the knee with thick, colourful ribbons or binders.

\section{G) Ornaments and Accessories}

Men liked to wear accessories and jewellery. Most of them hung swords on a sash. They also carried daggers, flint cases and pouches made of leather and silver that were embellished with beautiful engravings. Necklaces (Plate-1d) of Zi beads, turquoises, and ambers. The rich prefer 2 to 3 strings of corals or turquoise. Earrings made of copper, silver and gold with or without coral and turquoise. They also carry "Lokoo" which is a pocket to keep money. "Khau" is a box where they keep holy 
relics to protect them. "Loosong" is the hanging on the sash.
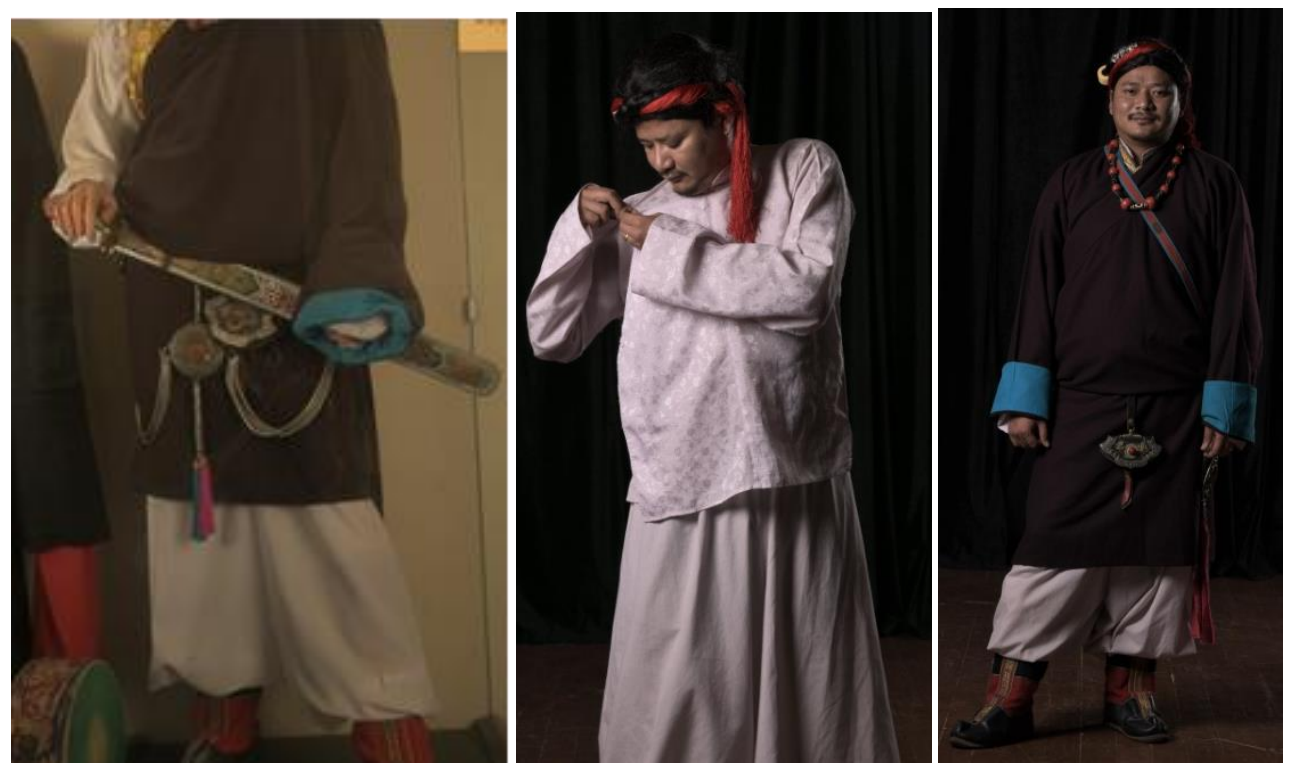

Figure 1: Khamba Mens Costume.
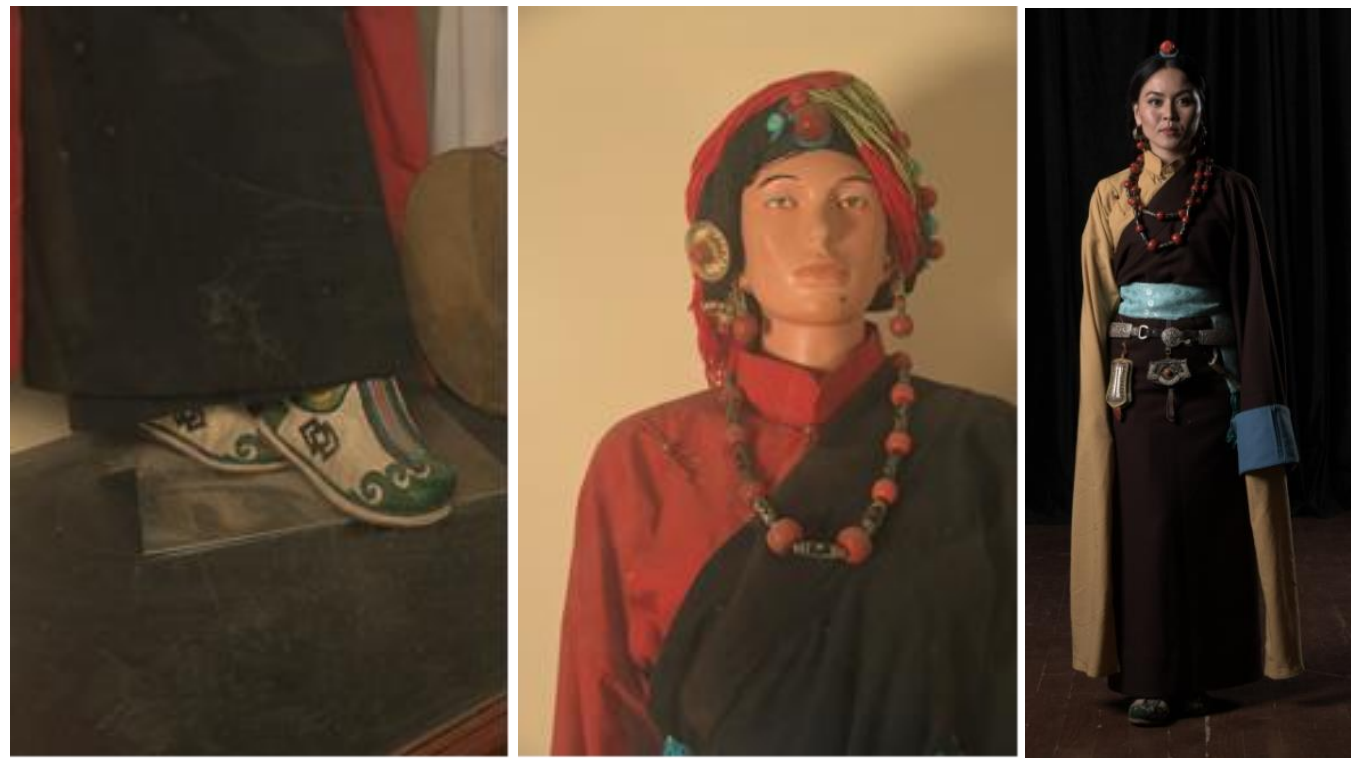

Figure 2: Khamba Womens Costume.

\section{Women Costume of Khamba Tribe: (Figure.2)}

The costumes of Khamba women were attractive, made of silk, brocade, cotton and wool fabrics. The different garments worn by them were:

\section{A) Chhupa}

Chhupa worn by khampa women were same as men with two or more pleats at back, dark coloured, sleeveless with deep 
Documentation on Traditional Costume of Khamba Tribe of Tibet in Exile-

armholes. The front neck area of these dresses had beautiful embroidered borders and some were made of rich brocades. The women from richer backgrounds preferred to wear brocade fabrics of bright colours like blue, green etc. and fur-trimmed robes. On the other hand weaker section women wore cotton or lower quality woollen robe in white or black colour which was directly originated from sheep. And brown colour was preferred by middle class people. Wealthy ones wore silk robes. For festivals, silk and brocade robes were trimmed with tiger, leopard or otter fur at the collars, sleeves and hems. They wore white or red shirts with high collars and red sashes.

\section{B) Shirt}

They wear Chinese collared shirts of cotton or silk of bright colours like red, yellow, white. The blouse had an asymmetrical opening and the total length is till waist. The garment is comprised of very long sleeves usually touched the feet of the wearer. Khamb women wore high collared, cotton or silk shirts in various colours, with white and red predominating. Some shirts had floral embroidery that ran from the top of the collar down to below the bosom. The sleeves were very long and broad. Some shirts were really dresses that came down to the ankles and served petticoats. This shirt was called Tenpo.

\section{C) Sash}

The wide sashes were made of various colours and had silk or cotton tassels that dangled down a women's side. They prefer wide red sash with cotton or silk tassels.

\section{D) Shoes}

They wore velvet cloth shoes which had designs of flowers or endless knots made of light blue or green goat leather named as "Galo" preferred by both richer and middle class Khampa women.

\section{E) Headgear}

Headdresses of ambers, corals and turquoises that were sewn onto broad strips of felt or leather were worn hanging down their backs. The Khamba women do not wear any headgear. The married Khamba women will be represented by Mardhen which runs from the middle of the forehead to back in a straight line.

\section{F) Ornaments}

The jewellery and accessories preferred were silver tassels of sil sil chains hanging from the back of their belts. They also wore a Chabma ("belt") made with engraved silver plates, a silver Losoong pendant that hung from the belt on the front left side, a small dagger / knife to eat meat and a small leather Bagu purse on the right side. They also wore gold or silver, turquoise and coral Butok earrings, which were teardrop-shaped named as Tarkosh. Syer-Na ("plain gold earring") and Chusin ("sea dragon") earrings were popular. They wore necklaces of corals, zis, ambes and turquoises attached to silver gau boxes that were embellished with turquoises and corals "Khapsu" to keep needle and thread.

\section{REFERENCES}

1. Central Tibetan Adminstration. (2010). Demographic Survey of Tibetans in Exile - 2009. Dharamshala, Himachal Pradesh, India: Planning Commision. 
2. Gyaltso, L. L. Tibetan Traditional Dress. McLeod Ganj, Himachal Pradesh, India: TIPA.

3. History of Tibet. New Delhi, Delhi, India: Har-Anand Publication.

4. Macdonald, D. Cultural Heritage of Tibet. New Delhi, India: Light \& Life Publishers.

5. Ramachandran, S. G. (1995). History of Tibet. New Delhi, Delhi, India: Har-Anand Publication.

6. Taklha, N. L. (2018). Costumes and Jewellery of Tibet. New Delhi, India: Archana Publisher.

7. The Department of Information and International Relations \& Central Tibetian Administration. (2014). Tibet at a Glance. Dharamshala, Himachal Pradesh, India: The Tibet Museum.

8. The Department of Information and International Relations, Central Tibetian Administration. (1996). Dharamshala - A Guide to Little Lhasa in India. Dharamshala, Himachal Pradesh, India.

9. Dolkar, Tashi, and HUMMARA AZIM. "Socio-Cultural Environment of Changpa Nomads of Changthang Region (Ladakh)." International Journal of Agricultural Science and Research (IJASR) 7.4 (2017): 491-496.

10. Jafri, Bushra. "Transcultural Identity in Vikram Seth's from Heaven Lake: Travels through Sinkiang and Tibet." International Journal of English and Literature (IJEL) 9.1, Feb 2019, 11-16

11. Desai, Falguni P. "The Immortals of Meluha: Relocating the Distant Land." International Journal of Mechanical and Production Engineering Research and Development (IJMPERD) 10.3, Jun 2020, 4507-4518

12. Jolden, Tsering, and Tashi Dolkar. "Change in the Authority and Status of the Aged: Emerging Challenges and Issues." International Journal of Humanities and Social Sciences (IJHSS) 6.1, Dec - Jan 2017; 1-8

\section{Picture Credits}

Tibetan Institute of Performing Arts, Mc leod Gunj, Kangra, HP 